\title{
DIET OF CHACEON RAMOSAE (DECAPODA, BRACHYURA) ON THE SOUTHERN BRAZILIAN EXCLUSIVE ECONOMIC ZONE
}

\author{
Sergio Santos Domingos ${ }^{1}$; Alessandro Augusto Rogick Athiê $\hat{e}^{2}$ and Carmen Lúcia Del Bianco \\ Rossi-Wongtschowski ${ }^{2}$ \\ ${ }^{1}$ Instituto de Biociências da Universidade de São Paulo \\ (Rua do Matão, travessa 14, 321, 05508-900, São Paulo, SP, Brasil) \\ sergiomoko@hotmail.com \\ ${ }^{2}$ Instituto Oceanográfico da Universidade de São Paulo \\ (Praça do Oceanográfico, 191, 05508-120, São Paulo, SP, Brasil) \\ aleathie@usp.br; cwongski@usp.br
}

Among the great variety of species exploited in the Brazilian Exclusive Economic Zone (EEZ), the brachyuran decapods of the genus Chaceon (Geryonidae) stand out for their high commercial value. There are two deep sea crab species inhabiting the southeastern and southern coastal waters of Brazil, Chaceon ramosae Manning, Tavares and Albuquerque, 1989 ("Royal Crab" or "Caranguejo Real") and Chaceon notialis Manning and Holthuis, 1989 ("Red Crab" or "Caranguejo Vermelho"). Crabs of the genus Chaceon are epibenthonic, inhabit muddy and muddy-sandy bottoms between 100 and $2800 \mathrm{~m}$ isobaths and are geographically widespread (DEFEO et al., 1992; MANNING ; HOLTHUIS, 1989). There is evidence that the species $C$. ramosae is restricted to the southern coast off the state of Santa Catarina, Brasil (ATHIÊ ;ROSSI-WONGTSCHOWSKI, 2004).

The diet of adult geryonid crabs has been described by several authors (GRAY, 1970; GERRIOR, 1981; FARLOW, 1980); like many deepsea organisms these animals present opportunistic feeding habits. Smaller crabs eat fish carcasses, dead squids, sponges, hydroids, gastropod, scaphopods and bivalve mollusks, small polychaete, crustaceans and probably tunicates (FARLOW, 1980). Bigger sized individuals feed upon the same benthic fauna and even on larger prey such as demersal fishes and squids.

Studies on the biology of geryonid crabs inhabiting Brazilian coastal waters are still few. The aim of the present study is to provide preliminary data on the composition of the diet of Chaceon ramosae living in the southern Brazilian EEZ.

The crabs were caught during samplings carried out for the REVIZEE Program (Living Resources in the Exclusive Economic Zone); it is important to note that the sampling occurred as part of a wider project and so collections were not directed specifically to the study of the diet, the specimens collected however have permitted a first assessment of the diet of the species.

$\overline{\text { Contr. No. } 875}$ do Inst. oceanogr. da Usp.
Specimens of $C$. ramosae were collected during expeditions of the research vessel "Soloncy Moura" (CEPSUL/IBAMA) at the coast of Santa Catarina, in the area located between the parallels $26^{\circ} 30^{\prime} \mathrm{S}-27^{\circ} 30^{\prime} \mathrm{S} ; 45^{\circ} \mathrm{W}-47^{\circ} 30^{\circ} \mathrm{W}$, between 100 and $600 \mathrm{~m}$ isobaths, using baited bottom traps (with fresh heads of Katsuwonus pelamis as bait), during September and October 2000.

A total of 66 specimens of Chaceon ramosae were analyzed. First, all the animals sampled were fixed with $10 \%$ buffered formaldehyde and then transferred to $70 \%$ alcohol. For each specimen cephalothorax length (CL) and cephalothorax width (CW) were measured in $\mathrm{mm}$ and body weight recorded in $\mathrm{g}$ using $0.01 \mathrm{~g}$ precision scale. After biometry, the stomachs were extracted and weighed and their contents analyzed after the excess of liquids external to this organ had been wiped off with tissue paper. The fullness level (FL) of the stomachs, which indicates the volume of the contents as a proportion of the maximum volume of the stomach (ZAVALACAMIN, 1996), was recorded as a percentage using the following scale: $\mathrm{FL}=0(0 \%$ empty $), \mathrm{FL}=1(1 \%$ $25 \%$ full $), \mathrm{FL}=2(26 \%-75 \%$ full $)$ and $\mathrm{FL}=3(76 \%-$ $100 \%$ full).

The identification of food items was made with the help of specialists from the Instituto Oceanográfico and the Museu de Zoologia, both from the Universidade de São Paulo, Brazil. Prey was identified either to species or to the lowest possible taxonomic level. Items that could not be identified were classified as Undetermined Organic Matter (UOM).

Considering that a whole prey is only rarely found, the number of ingested organisms cannot be taken to reconstitute the natural diet of brachyura (WILLIAMS, 1981). Because of the great number of items, the individual counting of which was impossible, it was decided not to analyze the numerical frequency of items. Thus, in the present study, the percentage frequency of occurrence (FO\%) and percentage biomass abundance $(\mathrm{M} \%)$ for each prey item and prey group were calculated in 
accordance with Hyslop's (1980) formula. From the percentage frequency of occurrence and percentage biomass abundance, the alimentary index (AI\%) was calculated using the modified formula of Kawakami and Vazzoler (1989):

$$
A I \%=\frac{\mathrm{FO} \% \times \mathrm{M} \%}{\sum(\mathrm{FO} \% \times \mathrm{M} \%)} X 100
$$

Variations in diet composition in relation to different depth strata were analyzed by using the $\mathrm{AI} \%$ data.

For the analyses of diet individuals were grouped by depth and three strata, $350 \mathrm{~m}, 450 \mathrm{~m}$ and $550 \mathrm{~m}$, were considered. In order to establish alimentary affinities among animals of the different strata, cluster analysis was performed using the Percentage of Similarity Index and the UPGMA method of hierarchical agglomeration (SNEATH; SOKAL, 1973). Cluster analysis was performed with the use of MVSP Plus software (Multivariate Statistical Package 3.1). A data matrix was obtained using $\mathrm{AI} \%$ values of items grouped in larger taxa, but this did not include the item UOM since this would not add any relevant information to the comparison of the diets.

The occurrence of Chaceon ramosae was confirmed at $60 \%$ of the 35 sampling stations; only the stations located on the $350 \mathrm{~m}, 450 \mathrm{~m}$, and $550 \mathrm{~m}$ isobaths presenting catches. The cephalothorax width of individuals ranged from $92.80 \mathrm{~mm}$ to $187.00 \mathrm{~mm}$ giving a mean CW of 129.23 ( \pm 19.11$)$; cephalothorax length ranged from $81.70 \mathrm{~mm}$ to $160.00 \mathrm{~mm}$, with a mean CL size of 111.63 ( \pm 15.89 ); and body weight ranged from $184.50 \mathrm{~g}$ to $1613.30 \mathrm{~g}$, with a mean weight of $564.57( \pm 269.68) \mathrm{g}$.

Of 66 stomachs, $3 \%$ were empty $(\mathrm{FL}=0)$, $33 \%$ were almost empty $(\mathrm{FL}=1), 40 \%$ presented $\mathrm{FL}=2$, and $24 \%$ were full $(\mathrm{FL}=3)$; of the stomachs containing some food, only $9.37 \%$ presented undigested contents, $49 \%$ had partially digested contents and $42 \%$ of them presented fully digested contents.

Forty-one items were identified in the diet of C. ramosae, including sediment and UOM. For items of minute size, recognizable crustaceans (with the exception of isopods) and synthetic material, only the frequency of occurrence was calculated. Excluding UOM and sediment, the items that predominated in terms of occurrence $(\mathrm{FO} \%)$ were: Teleostei $(63 \%)$, foraminifers $(22.7 \%)$, unidentified crustaceans $(9.0 \%)$, isopods $(7.5 \%)$ and unidentified cephalopods $(6.0 \%)$. Sediment was found in $45 \%$ of the foreguts and the high incidence of UOM (59.0\%) demonstrates the large quantity of material that, due to the high degree of digestion and maceration, was unidentifiable (Table $1)$.

In terms of biomass ( $\mathrm{M} \%)$, the highest values were found for Teleostei, UOM, isopods, Illex argentinus, unidentified crustaceans and sediment. The values of the AI\% confirm the importance of Teleostei, UOM, sediment, isopods and unidentified crustaceans (Table 1).

In view of the fact that all the C. ramosae individuals in this study were caught with fish-baited traps, it is possible that the value of the item teleostei has been overestimated and that this fact has therefore masked the true importance of other items. Thus, a second analysis was performed in which the item Teleostei was excluded. The analysis of $\mathrm{AI} \%$ showed that UOM, sediment, isopods and unidentified crustaceans were the most important items (Table 1). In order to quantify how important other items would be, Teleostei, UOM and sediment were excluded in a third analysis, and in this case isopods, unidentified crustaceans and unidentified Teuthoidea predominated (Table 1).

Analyzing the diet in relation to depth, it was discovered that Teleostei, UOM and sediment were present in more than $30 \%$ of the foreguts collected on the three depth strata (Table 2). Using the matrix obtained from the AI\% data (excluding UOM) for the cluster analysis it was detected that the diet of C. ramosae was very similar at all the three bathymetric strata analyzed. Two groups were formed on the basis of $88.2 \%$ similarity, that of $450 \mathrm{~m}$ and that of $350-550 \mathrm{~m}$, the latter with $93.9 \%$ similarity (Fig.1).

The diet of Chaceon ramosae was diversified and very similar on all the three depth strata considered $(350 \mathrm{~m}, 450 \mathrm{~m}$ and $550 \mathrm{~m})$. Some ideas arise with regard to this dietary similarity; one is that prey composition on this bathymetric gradient does not vary sufficiently to lead to significant differences in the diet. A second one is that some geryonid crabs are known to be very mobile, as in the case of Chaceon maritae off the coast of Namibia, where according to Melville-Smith (1987 apud Hines, 1990), mature females cover distances of $0.46 \mathrm{~km} /$ day. In the light of such mobility, crabs could easily cover the distances between the strata analyzed within a few hours, so distances within a $200 \mathrm{~m}$ depth range would be too short to result in differences in diet. However, further studies are necessary to verify how far its diet may vary with depth.

The analysis of animals caught with traps using heads and pieces of fish as bait does not permit to quantify the real importance of Teleostei in the diet because the bait itself introduces an error. However, in another study with Chaceon notialis collected exclusively by bottom trawl (DOMINGOS et al., 2007) Teleostei occurred in $25 \%$ of the foreguts, demonstrating that fish is indeed an important resource for that species. Considering that both species presented similar items in their diets, possibly, Teleostei is equally important in the diet of $C$. ramosae. 
Table 1. Frequency of occurrence (FO\%), biomass abundance (M\%) and alimentary index (AI\%) of items found in foreguts of Chaceon ramosae.

Al\%*: Alimentary Index calculated $w$ ithout teleostei

\begin{tabular}{|c|c|c|c|c|c|c|}
\hline Items & & FO\% & $\mathrm{M} \%$ & $\mathrm{Al} \%$ & $\mathrm{Al} \%{ }^{*}$ & $\mathrm{Al} \%^{* *}$ \\
\hline \multicolumn{7}{|l|}{ Osteichthyes } \\
\hline Teleostei & & 63.6 & 55.8 & 68.0 & & \\
\hline \multicolumn{7}{|l|}{ Mollus ca } \\
\hline Cephalopoda & & 6.1 & 0.7 & 0.1 & 0.3 & 4.4 \\
\hline & Teuthoidea & 4.5 & 1.7 & 0.1 & 0.5 & 8.0 \\
\hline & Illex argentinus & 1.5 & 4.9 & 0.1 & 0.4 & 7.7 \\
\hline Gastropoda & & 1.5 & 0.0 & 0.0 & 0.0 & 0.0 \\
\hline Crustacea & & 9.1 & 3.4 & 0.6 & 1.9 & 32.7 \\
\hline \multicolumn{7}{|l|}{ Brachyura } \\
\hline & Goneplacidae & 6.1 & & & & \\
\hline & Leucosiidae & 4.5 & & & & \\
\hline & Calappidae & 1.5 & & & & \\
\hline Thalassinidea & & 6.1 & & & & \\
\hline Hippoidea & & 1.5 & & & & \\
\hline Caridea & & 1.5 & & & & \\
\hline Palinuridea & & 1.5 & & & & \\
\hline \multicolumn{7}{|l|}{ Galatheidea } \\
\hline & Munida sp. & 1.5 & & & & \\
\hline Majidae & & 1.5 & & & & \\
\hline \multicolumn{7}{|l|}{ Maxillopoda } \\
\hline & Thecostraca (Cirripedia) & 1.5 & & & & \\
\hline \multicolumn{7}{|l|}{ Peracarida } \\
\hline & Isopoda & 7.6 & 5.9 & 0.9 & 2.7 & 47.2 \\
\hline
\end{tabular}

Nem atoda

Leptosomatidae

Annelida

Polychaeta

Echinoderm ata

Aphrodita sp $\quad 1.5$

Ophiuroidea

Foram inifera

Globigerina bulloides $\quad 1.5$

Globigerinita uvula $\quad 1.5$

Globigerinoides conglobatus $\quad 6.1$

Globigerinoides ruber pink $\quad 1.5$

Globigerinoides ruber white $\quad 12.1$

Globigerinoides sacculifer $\quad 9.1$

Globocassidulina sp. $\quad 3.0$

Globorotalia menardi $\quad 16.7$

Globorotalia sp. $\quad 1.5$

Globorotalia truncatulinoides $\quad 3.0$

Neogloboquadrina durtertrei $\quad 1.5$

Neogloboquadrina sp. $\quad 1.5$

Ammonia rolshawseni $\quad 1.5$

Cibicidoides sp. $\quad 10.6$

Lenticulina sp. $\quad 1.5$

Planulina sp. $\quad 3.0$

Quinqueloculina horrida $\quad 3.0$

Quinqueloculina sp. $\quad 1.5$

Uvigerina sp. 3.0

Undeterm ined Organic Matter (UOM) $\quad 59.1$

Sediment

$24.1 \quad 27.2 \quad 85.1$

Synthetic $m$ aterial

$\begin{array}{lll}3.4 & 2.9-9.2 \\ 0.1 & \end{array}$ 
Table 2. Frequency of occurrence (FO\%), biomass abundance (M\%) and alimentary index (AI\%) of items found in foreguts of Chaceon ramosae at the three depth strata considered. UOM = undertemined organic matter.

\begin{tabular}{l|ccc|ccc|ccc}
\cline { 2 - 10 } & \multicolumn{3}{c}{ 350 meters } & \multicolumn{3}{c|}{450 meters } & \multicolumn{3}{c}{550 meters } \\
\hline \hline Items & FO\% & M\% & Al\% & FO\% & M\% & Al\% & FO\% & M\% & Al\% \\
\hline \hline Teleostei & 60.0 & 60.3 & 77.6 & 65.6 & 56.1 & 59.1 & 64.3 & 47.1 & 57.0 \\
Cephalopoda & 10.0 & 14.6 & 3.1 & 9.4 & 0.4 & 0.1 & 21.4 & 9.6 & 3.9 \\
Crustacea & 20.0 & 12.8 & 5.5 & 12.5 & 3.3 & 0.7 & 28.6 & 14.2 & 7.6 \\
Nematoda & - & - & - & 3.1 & - & - & - & - & - \\
Polychaete & - & - & - & - & - & - & 7.1 & 0.1 & 0.0 \\
Foraminifera & 30.0 & - & - & 12.5 & - & - & 42.9 & - & - \\
UOM & 55.0 & 9.0 & 10.6 & 65.6 & 35.6 & 37.5 & 57.1 & 27.3 & 29.4 \\
Sediment & 50.0 & 3.0 & 3.2 & 37.5 & 4.6 & 2.8 & 64.3 & 1.8 & 2.2 \\
Synthetic material & 5.0 & 0.4 & - & - & - & - & - & - & - \\
\hline Total & - & 100.0 & 100.0 & - & 100.0 & 100.0 & - & 100.0 & 100.0 \\
\hline \hline
\end{tabular}

UPGMA (AI\%)

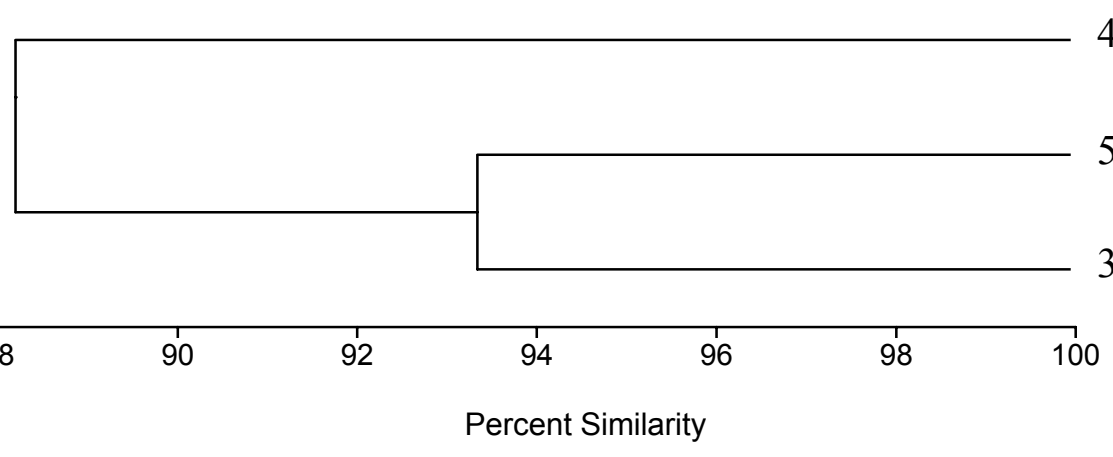

Fig. 1. Aggregation of foregut content samples, in accordance with the $\mathrm{AI} \%$, for $C$. ramosae individuals caught at different depth strata.

The presence of synthetic material, such as plastic and nylon, in the stomachs may indicate that these animals try to feed during the time they remain in the traps or are not selective consuming these items present on the substrate.

According to Cartes (1993), the presence of vertebras, otoliths and crystalline lenses of small fish in the foreguts of geryonids is an evidence of some degree of predatory activity. Similarly, the occurrence of these items and the occurrence of squid pens, suckers and crystalline lenses plus smaller crustaceans in foreguts of C. ramosae tend to reinforce the idea of active predation by this species.

Geryon longipes, another species of the Geryonidae family feeds upon a great variety of benthic invertebrates and is considered a scavenger, consuming mainly fish remains, for which the crab seeks actively (LAGARDĖRE, 1977 apud CARTES, 1993). In view of the fact that fishing that utilizes parts of fishes as bait is highly efficient we may affirm that necrophagy plays an important role in the diet of Chaceon ramosae.

Branco and Verani (1997) suggest that the ingestion of sand by Callinectes danae (Decapoda, Portunidae) occurs accidentally together with its prey; however, they also emphasize that it may be deliberate since the marine sediment is inhabited by a variety of microorganisms. Haefner (1990) considered sediment a source of carbonate and attests that it was the most frequent item in the diet of Callinectes ornatus. The present authors believe that the ingestion of sediment by Chaceon ramosae is both incidental and deliberate. 
C. ramosae present the habits both of scavengers and of active feeding (i.e. predation). Thus, based on these analyses it is possible to affirm that this species is an opportunistic carnivore.

\section{ACKNOWLEDGEMENTS}

This study was supported by $\mathrm{CNPq}$ (Conselho Nacional de Desenvolvimento Científico e Tecnológico) and by REVIZEE Program. We are grateful to the General Coordination of the REVIZEE Program/Score Sul. Our special gratitude is due to Dr. Gustavo A. S. Melo, Dr. Edmundo F. Nonato, Dra. Silvia Helena de Mello e Sousa and Dra. Rita Curvelo for their identification of crustacea, polychaeta, foraminifera and nematode, respectively.

\section{REFERENCES}

ATHIÊ, A. A. R. ; ROSSI-WONGTSCHOWSKI, C. L. D. B Os caranguejos-de-profundidade na Zona Econômica Exclusiva da Região Sudeste-Sul do Brasil: análise das operações de pesca e das capturas do N/P Kinpo Maru 58. 2004. 64 p. (Série Documentos REVIZEE - Score Sul).

BRANCO, J. O.; VERANI, J. R. Dinâmica da alimentação natural de Callinectes danae Smith (Decapoda, Portunidae) na lagoa da Conceição, Santa Catarina, Brasil. Revta. bras. Zool., v. 14, p. 1003-1018, 1997.

CARTES, J. E. Diets of deep-sea brachyuran crabs in the Western Mediterranean Sea. Mar. Biol., v. 117, p. 449457, 1993

DEFEO, O.; BAREA, L.; NIGGEMEYER, F.; LITTLE, V. Abundancia, distribución y dimensionamiento de la pesqueria del cangrejo rojo Geryon quinquedens Smith, 1879 en el Atlántico sudoccidental. Infme Téc. Instituto Nacional de Pesca, Montevideo, Uruguay, n. 38, 72 p., 1992.

DOMINGOS, S. S.; ATHIE, A. A. R.; ROSSIWONGTSCHOWSKI, C. L. D. B. Diet of Chaceon notialis (Decapoda, Brachyura) off the coast of Rio Grande, RS, Brazil. Braz. J. Oceanogr., v. 55 n.4. p. 327-329, 2007.

FARLOW, JR., J. O. Natural history and ecology of demersal fish-megafaunal invertebrate community from the upper continental slope off southern New England. Ph.D. dissertation. Yale University, New Haven, CT. , 1980. $430 \mathrm{p}$

GERRIOR, P. The distribution and effects of fishing on the deep-sea red crab, Geryon quinquedens Smith, off southern New England. 130 p. M.Sc. dissertation. Southeastern Massachusetts University, Massachusetts, USA, 1981.
GRAY, JR., G. W. Investigation of the basic life history of the red crab (Geryon quinquedens). Rhode Island Division of Conservation, Project 3-46R , Completion Report. NOAA-74062714, 1970. p. 1-35.

HAEFNER, JR., P. A. x. Natural diet of Callinectes ornatus (Brachyura: Portunidae) in Bermuda. J. Crustacean Biol., v. 10, n. 2, p. 236-246, 1970.

HINES, A. H. Commentary on life history and ecology of deep-sea crabs of the family Geryonidae. In: LINDBERG, W. J.; WENNER, E. L. (Ed.). Geryonid crabs and associated continental slope fauna: a research workshop report. Tech. Pap., Florida Sea Grant College, n. 58, p. 36, 1990.

HYSLOP, E. J. Stomach contents analysis - a review of methods and their application. J. Fish Biol., v. 17. p.411-429. 1980

KAWAKAMI, E. ; VAZZOLER, G. Método gráfico e estimativa do índice alimentar aplicado no estudo de alimentação de peixes. Bolm Inst. oceanogr., S. Paulo, v. 29 , n. 2, p. 205-207, 1989.

LAGARDÈRE, J. P. Recherches sur la distribution vertical et sur l'alimentation des crustacés decapodes benthiques de la Pente Continentale du Golfe de Gascogne. Analyses des groupements carcinologiques. Bull. Cent. Étud. Rech. scient. Biarritz, v. 11, p. 367-440, 1977.

MANNING, R. B. ; HOLTHUIS, L. B. Two new genera and nine new species of geryonid crabs (Crustacea, Decapoda, Geryonidae). Proc. biol. Soc. Wash., v. 102, n.1, p. $50-77,1989$

MANNING, R.B.; TAVARES, M.S.; ALBUQUERQUE, E.F. Chaceon ramosae, a new deep-water crab from Brazil (Crustacea: Decapoda:Geryonidae). Proc. biol. Soc. Wash., v. 102, 3, p. 646-650, 1989.

MELVILLE-SMITH, R. Movements of deep-sea red crab (Geryon maritae) off South West Africa/Namibia. S. Afr. J. Zool., v. 22, p. 143-152, 1987.

SNEATH, P. H. A.; SOKAL, R. R. Numerical taxonomy. San Francisco: W. H. Freeman and Company, 1973. 573 p.

WILIAMS, M. J. Methods for analysis of natural diet in portunid crabs (crustacea: decapoda: portunidae). J. exp. mar. Biol. Ecol., v. 52, p. 103-113, 1981.

ZAVALA-CAMIN, L. A. Introdução aos estudos sobre alimentação natural em peixes. Maringá, PR: EDUEM, 1996. 129 p.

(Manuscript received 10 November 2006; revised 11 June 2007; accepted 05 July 2007) 